Article

\title{
Investigation into Effect of Natural Shellac on the Bonding Strength of Magnesium Substituted Hydroxyapatite Coatings Developed on Ti6A14V Substrates
}

\author{
Ritwik Aravindakshan*(D), Kaiprappady Kunchu Saju and Reghuraj Aruvathottil Rajan \\ Department of Mechanical Engineering, School of Engineering, Cochin University of Science \& Technology, \\ Kochi 682022, India; kksaju@cusat.ac.in (K.K.S.); reghuraj@alameen.edu.in (R.A.R.) \\ * Correspondence: ritwik@tistcochin.edu.in
}

check for updates

Citation: Aravindakshan, R.; Saju, K.K.; Aruvathottil Rajan, R. Investigation into Effect of Natural Shellac on the Bonding Strength of Magnesium Substituted

Hydroxyapatite Coatings Developed on Ti6Al4V Substrates. Coatings 2021, 11, 933. https://doi.org/10.3390/ coatings11080933

Academic Editor: Liviu Duta

Received: 30 June 2021

Accepted: 29 July 2021

Published: 4 August 2021

Publisher's Note: MDPI stays neutral with regard to jurisdictional claims in published maps and institutional affiliations.

Copyright: (c) 2021 by the authors. Licensee MDPI, Basel, Switzerland. This article is an open access article distributed under the terms and conditions of the Creative Commons Attribution (CC BY) license (https:/ / creativecommons.org/licenses/by/ $4.0 /)$.

\begin{abstract}
The bioactive and biocompatible properties of hydroxyapatite (HA) promote the osseointegration process. To enhance other bio-functions of HA such as improving the antibacterial property of the implant, increasing the rate of cell proliferation, or improving tissue generation capability, HA is substituted with many elements such as $\mathrm{Zn}, \mathrm{Cl}, \mathrm{Ba}, \mathrm{Fe}, \mathrm{Cu}, \mathrm{Ag}, \mathrm{Sr}, \mathrm{F}, \mathrm{Na}$, etc. This study reports development of Magnesium substituted $\mathrm{HA}\left(\mathrm{Mg}-\mathrm{HA}\right.$ ) coatings on $\mathrm{Ti}_{6} \mathrm{Al}_{4} \mathrm{~V}$ substrates using the dip coating technique. To improve the adhesion and stability of the coating, an intermediate layer of shellac was applied between the coating and Ti6Al4V substrate. The dip coating process parameters were optimized using the Taguchi technique and it was found that dipping time of $35 \mathrm{~s}$ and $13 \% w / w$ of shellac concentration provided the maximum bonding strength of $12.5 \mathrm{MPa}$. The biocompatibility, dissolution, and corrosion study of the developed coating using the optimal parameters obtained were carried out in this study. An improvement in cell growth and cell proliferation was observed in the extract medium prepared from coated substrates. Release of $\mathrm{Ca}, \mathrm{P}$ and $\mathrm{Mg}$ ions from the surface of the coated substrate into the simulated body fluid (SBF) was found to be almost constant which shows the stability of the thin film coating formed. The Mg-HA coated substrate also exhibited better corrosion resistance than the uncoated substrate.
\end{abstract}

Keywords: Mg-HA; dip-coating; shellac; Taguchi technique

\section{Introduction}

Hydroxyapatite $\left(\mathrm{Ca}_{10}\left(\mathrm{PO}_{4}\right)_{6}(\mathrm{OH})_{2}\right)(\mathrm{HA})$ is one of the prominent biomaterials among all other calcium phosphate ceramics used. It has been commercially used since the 1980s because of its biocompatibility and osteoconductive properties [1]. HA exhibited a composition similar to the bone minerals phase and it has been widely used for orthopedic and dental applications [2]. Researchers tried to modify the structural composition of HA to improve its bio-functionality. The naturally formed bio-apatite has trace amounts of fluoride, magnesium, sodium, potassium, carbonate, chloride, zinc, barium, iron, strontium, copper, etc [3,4]. Studies showed that the incorporation of different foreign cations and anions into synthetic HA structures enhanced its osteoblastic response [5]. HA in general, is brittle and is not suitable for load-bearing applications. To overcome this disadvantage, HA coating is developed on metallic substrates [2]. Commercially pure titanium (CpTi), titanium alloys, stainless steel, and cobalt-chromium ( $\mathrm{Co}-\mathrm{Cr}$ ) alloys are mainly used as substrates because of their bio-compatibility and superior mechanical properties [6].

In recent years, various types of substituted HA were developed by researchers. Many of them processed it in form of scaffolds and some others deposited it as a thin film coating on metal substrates. A considerable amount of literature showed the presence of zinc $(\mathrm{Zn})$ in the human body. It plays a vital role in enzyme activity, nucleic acid metabolism, hormonal activity, and bio-mineralization. $\mathrm{Zn}$ is one of the important minerals found in human teeth. Studies also showed that $\mathrm{Zn}$ incorporation into metal implants promotes 
bone formation [7]. Zn substituted HA (Zn-HA) was used as an alternative material for autograft and allograft bone replacements. Studies reported contradictory findings on the crystalline nature of HA structure when substituted with Zn cations [8]. Few other studies showed that silicon substituted HA (Si-HA) promotes osteoblast cell activity and apatite formation in simulated body fluid (SBF) compared to pure HA. Silicon is essential for bone mineralization and soft tissue development [2].

Bacterial infection post-implant placement is very serious and many studies showed that the success of the implant over a while depends on its antibacterial property. Silver $(\mathrm{Ag})$ is a key element with antibacterial properties. Ag substituted HA (Ag-HA) related studies showed that substituting $\mathrm{Ag}^{+}$ions into the crystal lattice structure of $\mathrm{HA}$ can control bacterial infection significantly [9]. Another researcher showed that adding titanium dioxide $\left(\mathrm{TiO}_{2}\right)$ into $\mathrm{Ag}$-HA can kill almost $98 \%$ of S. aureus and $99 \%$ of E. coli bacteria [10]. The potential cytotoxic effect of $\mathrm{Ag}$ in the Ag-HA compound was reduced by doping strontium (Sr). Ag-HA/Sr was seen to augment the cell proliferation in a better way compared to the Ag-HA [1]. Strontium substituted HA (Sr-HA) was also studied extensively. It was shown that $\mathrm{Sr}-\mathrm{HA}$ can enhance pre-osteoblastic cell replication. SR-HA also inhibits the activity of osteoclasts [5].

Chitosan ((1,4)-2-amino-2-deoxy- $\beta$-D-glucan) is a partially deacetylated form of chitin, which is abundantly produced from marine copepods [11]. Chitosan substituted HA (CS-HA) was used to enhance tissue regenerative efficacy and osteoconductivity. To improve mechanical strength, HA was incorporated into the chitosan polymer [12]. Some researchers showed that CS-HA composite scaffolds have better cell proliferation compared to chitosan scaffolds [13]. Studies also showed that a chitosan polymer offers the advantage of low-temperature processing of composite materials [14]. Researchers also developed novel HA-silica-chitosan composites (HA-CS-SiO ${ }_{2}$ ). This composite showed lower porosity which can be used for developing laminates [15].

Lithium ( $\mathrm{Li}$ ) is a bioelectric material and very few studies have been carried out to analyze its biocompatibility. Researchers demonstrated that adding Li decreases the solubility of $\mathrm{HA}$ and it is a good indication of biocompatibility. Lithium substituted HA (Li-HA) showed good adherence to osteoblasts [16]. Carbonate substituted $\mathrm{HA}\left(\mathrm{CO}_{3}-\mathrm{HA}\right)$ has been explored by many. $\mathrm{CO}_{3}$-HA mimics the chemical composition of hard tissue. It is also reported to be thermally stable as it would not decompose into undesirable secondary phases at high calcination temperatures [17].

Magnesium (Mg) substituted HA (Mg-HA) was investigated in detail for the last few decades. Studies showed that Mg-HA stimulates cell proliferation [18]. Mg-HA, due to its ion exchanging properties is known to be highly toxic to microbes and is used to control bacterial growth [19]. It also can enhance the osteoblast bonding strength. Researchers demonstrated that $\mathrm{Mg}$-HA is more biocompatible than phase pure HA [20].

Apart from being a biocompatible material, $\mathrm{Mg}$-HA has wide clinical applications. It has the potential to improve angiogenesis which is the fundamental requirement for bone regeneration. Bone neo-formation was also observed during in vivo studies conducted with Mg-HA [21]. Clinical studies pertaining to the use of Mg-HA in dental application received much attention lately. Because of decay or damage, a tooth might have to be removed from its position and an extraction socket is formed there. Immediately placing an implant directly to the extraction socket might not be practically viable and compatible. Studies showed that filling these sockets with Mg-HA prior to implant placement provides better results [22].

Digital dentistry techniques such as coherent-scatter computed tomography (CSCT) and cone-beam computed tomography (CBCT) have been used to measure the concentration of HA [23,24]. Recently 3D printing of substituted HA is evolving as a forefront technology $[25,26]$. Robust Mg-based scaffolds have also been 3D printed for promoting the osteointegration process [27].

Various methods have been adopted for developing a substituted-HA coating on metal substrates. Coating methods such as the sputtering process, sol-gel technique, 
electrophoretic method, plasma spray technique, etc., have been used. This study reports development of a thin film of Mg-HA on titanium alloy (Ti6Al4V) using a dip coating technique. It was observed that the coating thus developed has poor bonding strength. To enhance the bonding strength, an intermediate shellac layer (natural resin) was applied between the coating film and substrate. The Taguchi optimization technique was employed to obtain optimal parameters for developing Mg-HA Coating on Ti6Al4V materials. The dissolution rate, cell viability, and corrosion behavior of the developed coating were also studied as part of this research work.

\section{Materials and Methodology}

\subsection{Mg-HA Preparation}

Analytical grade of diammonium hydrogen phosphate $\left(\left(\mathrm{NH}_{4}\right)_{2} \mathrm{HPO}_{4}\right.$, Nice Chemicals Ltd., Kochi, India), calcium nitrate tetrahydrate $\left(\mathrm{Ca}\left(\mathrm{NO}_{3}\right)_{2} \cdot 4 \mathrm{H}_{2} \mathrm{O}\right.$, Nice Chemicals Ltd., Kochi, India), magnesium chloride hexahydrate $\left(\mathrm{MgCl}_{2} \cdot 6 \mathrm{H}_{2} \mathrm{O}\right.$, Nice Chemicals Ltd., Kochi, India), and ammonium hydroxide $\left(\mathrm{NH}_{4} \mathrm{OH}\right.$, Nice Chemicals Ltd., Kochi, India) were used for the preparation of nano-sized Mg-HA. It was prepared as per the methodology reported in reference [18]. Aqueous diammonium hydrogen phosphate was added to the solution having magnesium chloride hexahydrate and calcium nitrate tetrahydrate in a drop-wise manner. The molar ratio of $\mathrm{Mg} / \mathrm{Ca}$ was 0.18 and the $\mathrm{pH}$ value was maintained at 11 . The mixture was stirred for 24 hours continuously using a magnetic stirrer. The precipitate thus formed was further centrifuged and then washed with distilled water. The substrates thus formed were dried at $70^{\circ} \mathrm{C}$ overnight and then sintered at $900{ }^{\circ} \mathrm{C}$ for one hour. The elemental composition of as-prepared $\mathrm{Mg}$-HA is shown in Table 1.

Table 1. Elemental Composition.

\begin{tabular}{cccccc}
\hline Material & \multicolumn{5}{c}{ Elemental Composition (\%) } \\
\hline Ti6Al4V & $89.7 \% \mathrm{Ti}$ & $6.1 \% \mathrm{Al}$ & $3.9 \% \mathrm{~V}$ & $0.3 \% \mathrm{Fe}$ & - \\
\hline $\mathrm{Mg}-\mathrm{HA}$ & $43.31 \% \mathrm{O}$ & $7.79 \% \mathrm{Mg}$ & $15.08 \% \mathrm{P}$ & $0.25 \% \mathrm{Cl}$ & $33.57 \% \mathrm{Ca}$ \\
\hline
\end{tabular}

\subsection{Characterization of $\mathrm{Mg}-\mathrm{HA}$}

The surface morphology of the as-prepared Mg-HA nanopowders was analyzed using scanning electron microscopy (SEM, JEOL JSM-6390LV, JEOL Ltd., Tokyo, Japan). Highresolution transmission electron microscopy (HR-TEM, JEOL JEM 2100, JEOL Ltd., Tokyo, Japan) was used to analyze the crystalline morphology of the nanopowders prepared. Energy-dispersive X-ray spectroscopy (EDS, Oxford XMX N, Wiesbaden, Germany) was used to quantify elemental composition of Mg-HA. The crystallinity of the powders was characterized using the X-ray powder diffraction (technique (XRD, Bruker AXS D8, Bruker AXS, Berlin, Germany)).

\subsection{Experiment Methodology}

Ti6Al4V (grade 5) substrates of dimensions $10 \mathrm{~mm} \times 20 \mathrm{~mm} \times 2 \mathrm{~mm}$ thickness were used as base substrates. The composition of the substrate used is shown in Table 1. Initially, the substrates were scoured using emery papers of grit size ranging from 80 to 400 . The substrates were then sandblasted to remove any impurities on the surface [28]. Further, they was soaked in the acetone solution, sonicated for $45 \mathrm{~min}$, and then they were air-dried. The coating procedure was carried out on a custom-fabricated dip coating apparatus. The substrate after being dipped in shellac solution was then dipped further in Mg-HA solution.

Natural shellac is produced from lac insects (Laccifer Lacca) and it acts as a bio-resin [29]. The shellac layer imparts adhesion to the coating. The strength of the coating formed on the substrates is dependent on various coating parameters. Parameters such as dipping duration, dipping and withdrawal speed, the concentration of the dipping solution, and temperature. The shellac solution was prepared by varying the concentration of shellac in ethanol. Three different concentrations of shellac were considered in this study. Con- 
centrations of $12.5 \%(w / w), 13.0 \%(w / w)$ and $13.5 \%(w / w)$ were fixed after conducting numerous trial experiments. It was seen that a concentration less than $12.5 \%$ does not help in producing a stable coating. Similarly, a concentration of more than $13.5 \%$ affected the uniformity of the coating. The dipping time in the shellac solution varied from 15 to $35 \mathrm{~s}$. Experiment trials showed that a duration less than $15 \mathrm{~s}$ in shellac solution did not yield any coating and more than 35 s produced thicker coating which was undesirable.

$\mathrm{Mg}-\mathrm{HA}$ solution for the dip coating process was prepared using as-developed $\mathrm{Mg}-\mathrm{HA}$ as the solute and ethanol (99.99\% purity) as the solvent. Glycerin and polyethylene glycol (PEG 600, Nice Chemical Ltd., Kochi, India) were used from a stable solution [30]. Magnetic stirring was performed for 8 hours at room temperature to obtain a homogenous solution. The concentration of Mg-HA in the Mg-HA solution was maintained at $20 \%(w / w)$. The dipping time for the HA solution was fixed at $25 \mathrm{~s}$. The dipping and withdrawal speed for shellac and Mg-HA solution was fixed as $15 \mathrm{~mm} / \mathrm{min}$. The schematic diagram of the coating process and layer by layer coating is illustrated in Figure 1. In this study, all the experiments were carried out at room temperature.

\section{Step 1}

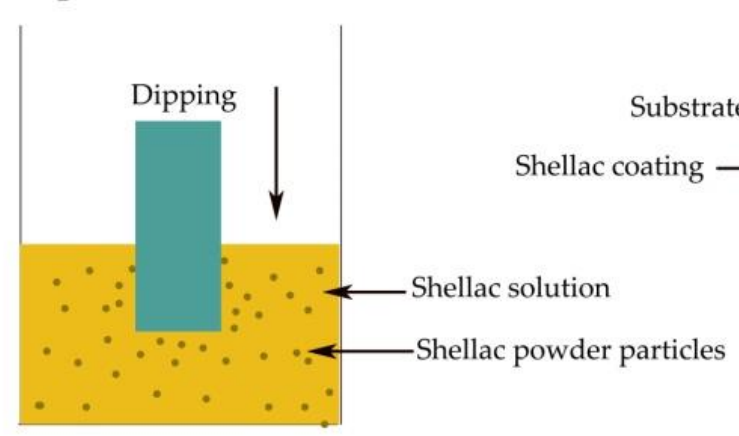

Step 3
Step 2 Withdrawl

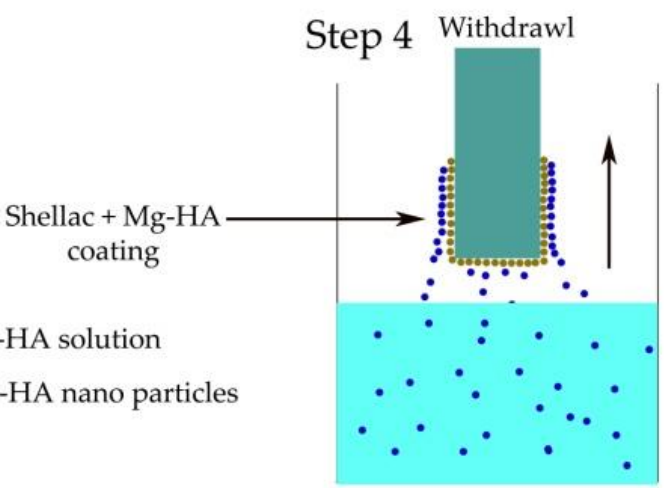

(a)

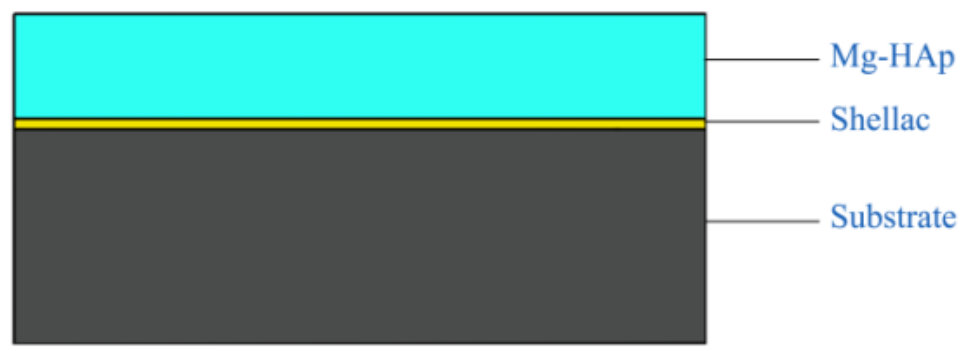

(b)

Figure 1. Schematic diagram of the coating process and coated substrate. (a) Schematic diagram of the coating process; (b) coated substrate. 


\subsection{Bonding Strength and Thickness}

The bonding strength of the coating was measured using the standard pull-out test equipment following ASTM D 7234 standard [31] and the thickness of the coating was measured following the IS- 3203-2001 standards [32].

\subsection{Optimization}

For optimization of coating parameters, the Taguchi technique was used. The parameters considered in this study are dipping time and shellac concentration (Table 2). The required response was the bonding strength. Statistical software package Minitab was employed to perform signal-to-noise $(\mathrm{S} / \mathrm{N})$ ratio calculations, analysis of variance (ANOVA), and to obtain a regression equation. $\mathrm{S} / \mathrm{N}$ ratio gives the ratio of mean to standard deviation. ANOVA provides details of the percentage contribution of each parameter towards the bonding strength. Likewise, the relationship between the coating parameters and the bonding strength is put into a mathematical model using regression analysis. The strength of the obtained model is validated by defining the value of the coefficient of determination $\left(R^{2}\right)$.

Table 2. Levels of parameters.

\begin{tabular}{cccc}
\hline \multirow{2}{*}{ Parameters } & \multicolumn{3}{c}{ Experiment Levels } \\
\cline { 2 - 4 } & $\mathbf{1}$ & $\mathbf{2}$ & $\mathbf{3}$ \\
\hline Dipping time $(\mathrm{s})\left(\mathrm{w}_{1}\right)$ & 15 & 25 & 35 \\
Shellac concentration $(w / w \%)\left(\mathrm{w}_{2}\right)$ & 12.5 & 13.0 & 13.5 \\
\hline
\end{tabular}

\subsection{In Vitro Studies}

The substrate coated with optimal parameters was further investigated for its dissolution, in vitro, and corrosion behavior. The dissolution studies of $\mathrm{Mg}$-HA were conducted by soaking substrates in simulated body fluid (SBF) for 4 weeks. Preparation of SBF was carried out using Kokubo methodology [33] where the $\mathrm{pH}$ value was maintained between 7.3 and 7.4. SBF ionic concentration is quantified using inductively coupled plasma-mass spectrometry (ICP-MS). The coated substrates were soaked in $20 \mathrm{~mL}$ of SBF without shaking at $37 \pm 0.5^{\circ} \mathrm{C}$ following ISO 10993-14 standards [34]. The rate at which the dissolution of calcium $(\mathrm{Ca})$, phosphorous $(\mathrm{P})$, and magnesium $(\mathrm{Mg})$ ions occurred was recorded for 4 weeks.

MG-63 osteosarcoma human cell line was utilized to perform cell viability studies following ISO 10993-12 [35]. A 96-well plate was used in this study and each cell was seeded with 10,000 cells. A complete medium $(\mathrm{CM})$ was prepared by adding a minimum essential medium (MEM) and $10 \%$ fetal bovine solution (FBS). It was incubated at $37^{\circ} \mathrm{C}$ in $5 \% \mathrm{CO}_{2}$ for a 24 hour duration. To prepare the cell culture medium (CCM), cells were seeded to the CM. As the thin layer of a coated substrate cannot be peeled off, an extract medium is to be prepared. The extract medium preparation is carried out by soaking the coated substrates in CM for 24 hours. Before soaking, it is ensured that all the substrates were ethylene oxide (ETO) sterilized. After carefully removing the substrate from CM, it was further was diluted to $12.5 \%, 25 \%$ and 50\% CCM. For quantification of cell viability, assay was utilized. The absorbance value from the assay was recorded using a TECAN microplate reader at $595 \mathrm{~nm}$.

\subsection{Corrosion}

Usually, substrates are susceptible to various types of corrosion attacks. Pitting corrosion, crevice corrosion, galvanic corrosion, fretting corrosion and corrosion fatigue are some common types of corrosion that are normally found in substrates [36]. In this study, the potentiodynamic polarization test (Metrohm Autolab, Chennai, India) was performed following ASTM G5-94 [37]. The substrates were exposed to a simulated body fluid environment in a three-electrode electrochemical cell. Here, platinum was the counter 
electrode, saturated calomel electrode (SCE) was the reference electrode, and the substrates were kept as the working electrode.

The potentiodynamic polarization curve was obtained for the coated and uncoated substrates with a stabilization period of $3600 \mathrm{~s}$ and the electrode potential range was varied from -1000 to $1000 \mathrm{mV}$. The scanning rate was $0.005 \mathrm{mVs}^{-1}$. The corrosion potential $\left(\mathrm{E}_{\text {corr }}\right)$, polarization resistance $\left(R_{p}\right)$, anodic Tafel slope $\left(\beta_{a}\right)$, and cathodic Tafel slope $\left(\beta_{c}\right)$ were measured during this study to analyze the corrosion effect.

\section{Results and Discussions}

\subsection{Surface Morphology and Characterization}

The as-prepared Mg-HA powders are spherical in appearance in Figure 2. It is observed that the powder particles are tightly packed with very little porosity. The tighter packing might be a result of $\mathrm{Mg}^{2+}$ ions occupying the vacant $\mathrm{Ca}^{2+}$ sites. Previous studies showed that the spherical-sized particles transform themselves into needle-like structures during apatite formation [38].

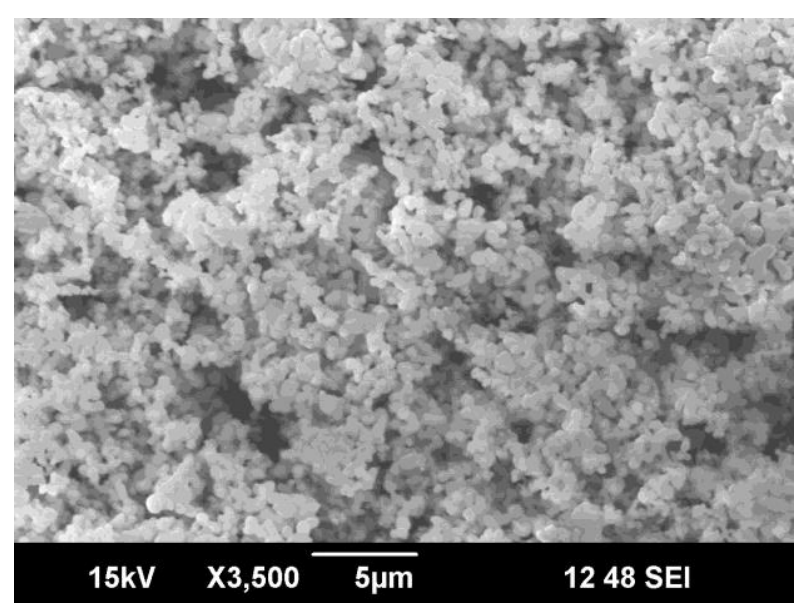

Figure 2. SEM micrograph of as-prepared Mg-HA.

Figure 3 shows high-resolution TEM images of the Mg-HA nanopowders. The nanopowder size varied from 50.28 to $98.20 \mathrm{~nm}$. The average size of the powders was observed to be $\sim 65 \mathrm{~nm}$. Each nanoparticle has a definite shape and can be seen agglomerating. The nano size of the particles makes it easier to form a stable and uniformly suspended dip coating solution.

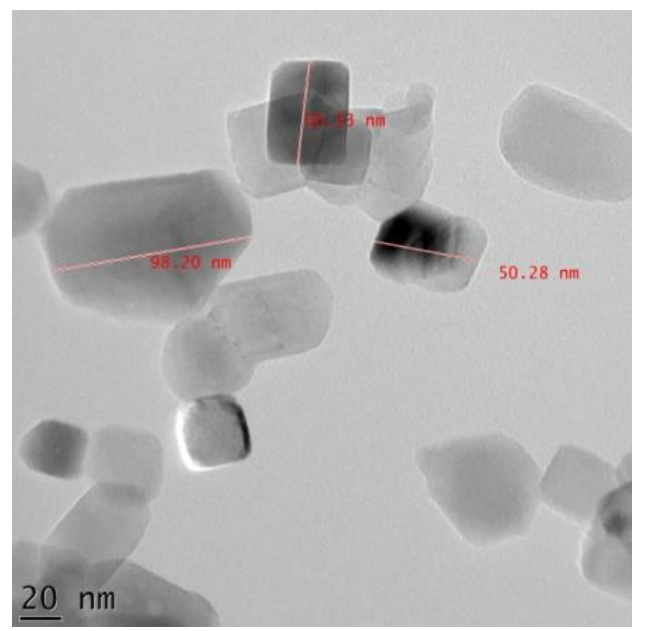

Figure 3. HR-TEM image of as-prepared Mg-HA. 
EDS analysis was carried out to identify different elements in the as-prepared Mg-HA nanopowders. Characteristic peaks of $\mathrm{O}, \mathrm{Mg}, \mathrm{P}, \mathrm{Cl}$ and $\mathrm{Ca}$ can be observed in Figure 4 and its corresponding atomic percentage is also presented. Presence of $\mathrm{Mg}, \mathrm{Ca}$ and $\mathrm{P}$ indicate that $\mathrm{Mg}$ has entered into the lattice structure of $\mathrm{HA}$, which corroborates studies previously conducted [39].

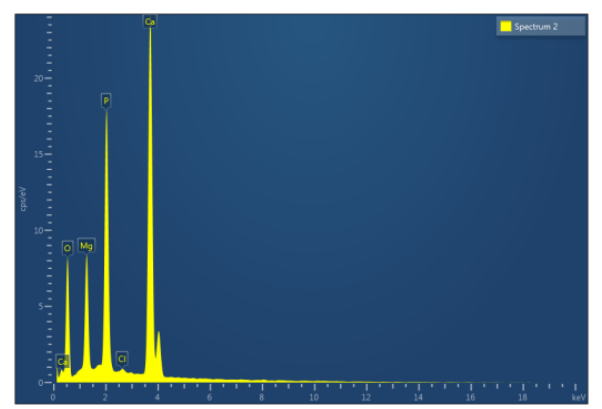

\begin{tabular}{|c|c|}
\hline Element & Atomic \% \\
\hline $\mathrm{O}$ & 63.11 \\
\hline $\mathrm{Mg}$ & 7.59 \\
\hline $\mathrm{P}$ & 11.15 \\
\hline $\mathrm{Cl}$ & 0.13 \\
\hline $\mathrm{Ca}$ & 18.02 \\
\hline
\end{tabular}

Figure 4. EDS spectra of as-prepared Mg-HA.

X-ray diffraction characterization of as-prepared Mg-HA is shown in Figure 5. Crystalline phases were identified by comparing them with JCPDS standards. A HA crystalline structure is observed at a $2 \theta$ value of $27.808^{\circ}$ and $31.113^{\circ}$ which is in good agreement with JCPDS No. 09-432. The $\mathrm{Mg}(\mathrm{OH})_{2}$ crystalline phase was observed at a $2 \theta$ value of $34.463^{\circ}$, confirmed by JCPDS No. 07-0239. The MgO phases are also seen in the XRD profile between the $2 \theta$ value of $48^{\circ}$ and $55^{\circ}$. In the XRD profile, an amorphous phase is seen at the beginning. It is due to the incorporation of $\mathrm{Mg}^{2+}$ ions into the HA structure. Studies showed that an increase in magnesium content can lead to an amorphous phase [40].

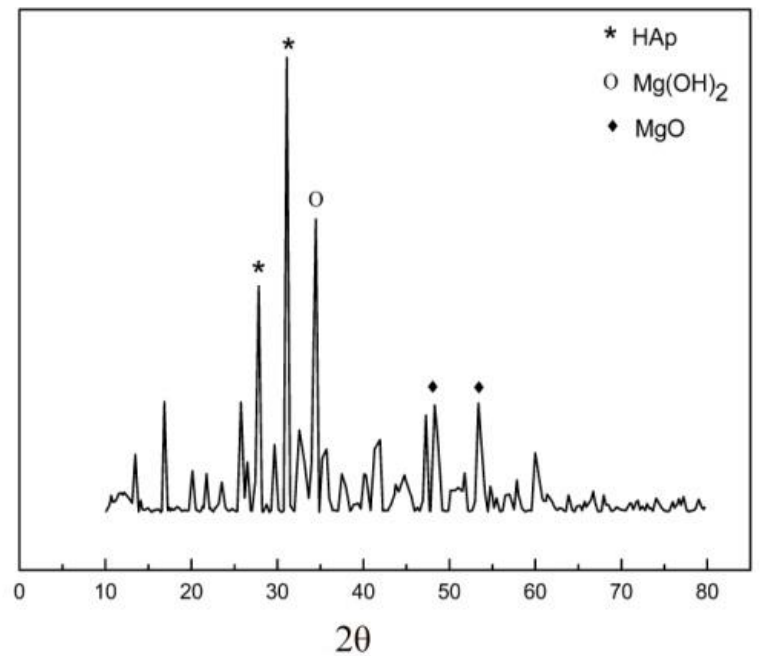

Figure 5. XRD of as-prepared Mg-HA.

\subsection{Bonding Strength and Thickness Measurement}

A thin film of Mg-HA coating was developed on Ti6Al4V substrates using the asprepared Mg-HA precursor powder. A thin layer of shellac applied between the substrate and HA coating provided stability and improved bonding strength of Mg-HA coatings. The thickness of shellac coating applied in between was measured as $2 \mu \mathrm{m}$ and the total $\mathrm{Mg}$-HA thickness was measured as $12 \mu \mathrm{m}$. Mg-HA coating developed on the substrate without shellac has a bonding strength of $1.19 \mathrm{MPa}$. A tremendous increase in the bonding strength could be observed because of the application of natural shellac. 


\subsection{SBF Composition}

Table 3 shows the ionic concentration of the prepared SBF measured using inductively coupled plasma mass spectrometry (ICP-MS, Thermo Fisher Scientific, Mumbai, India). It was observed that SBF had a similar ionic concentration as that of human blood [28]. It mimics the real human body environment.

Table 3. Composition of human blood and SBF prepared.

\begin{tabular}{ccc}
\hline Ionic Concentrations & Human Blood (ppm) & SBF Prepared (ppm) \\
\hline $\mathrm{Na}^{+}$ & 142.0 & 136.0 \\
\hline $\mathrm{Cl}^{-}$ & 103.0 & 107.0 \\
\hline $\mathrm{HCO}_{3}{ }^{-}$ & 27.0 & 21.0 \\
\hline $\mathrm{K}^{+}$ & 5.0 & 8.0 \\
\hline $\mathrm{Mg}^{2+}$ & 1.5 & 2.0 \\
\hline $\mathrm{Ca}^{2+}$ & 2.5 & 3.0 \\
\hline $\mathrm{HPO}_{4}{ }^{2-}$ & 1.0 & 0.5 \\
\hline $\mathrm{SO}_{4}{ }^{2-}$ & 0.5 & 0.3 \\
\hline
\end{tabular}

\subsection{Optimization Results}

The values of bonding strength and corresponding $\mathrm{S} / \mathrm{N}$ ratios for various combinations of experiments are shown in Table 4. The mean effect plot is shown in Figure 6. It can be seen that substrate with code $\mathrm{H}$ (dipping time $35 \mathrm{~s}$ and shellac concentration of $13.0 \% w / w)$ provides the maximum bonding strength.

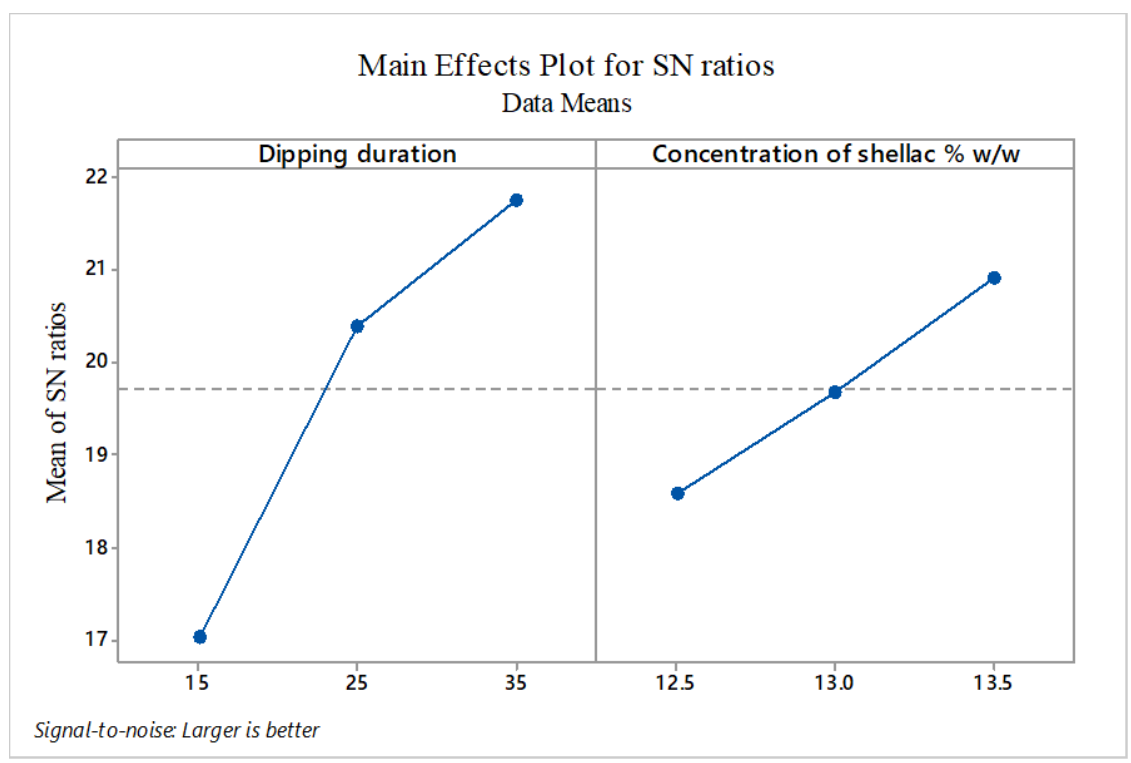

Figure 6. Coating parameters effect on bonding strength. 
Table 4. Measured experimental values with S/N ratio.

\begin{tabular}{ccccc}
\hline \multicolumn{5}{c}{ Orthogonal Array with Parameters } \\
\hline Substrate Code & Dipping Time $(\mathbf{S})\left(\mathbf{w}_{\mathbf{1}}\right)$ & $\begin{array}{c}\text { Concentration of } \\
\text { Shellac } \mathbf{\%}(\boldsymbol{w} / \mathbf{w})\left(\mathbf{w}_{\mathbf{2}}\right)\end{array}$ & $\begin{array}{c}\text { Bonding Strength } \\
\mathbf{( M P a})\end{array}$ & $\begin{array}{c}\text { Bonding Strength(S/N } \\
\text { Ratio) }\end{array}$ \\
\hline A & 1 & 1 & 5.9 & 15.417 \\
B & 1 & 2 & 6.7 & 16.521 \\
C & 1 & 3 & 9.1 & 19.181 \\
D & 2 & 1 & 8.8 & 18.890 \\
E & 2 & 2 & 10.7 & 20.588 \\
F & 2 & 3 & 12.1 & 21.656 \\
G & 3 & 1 & 11.8 & 21.438 \\
H & 3 & 2 & 12.5 & 21.938 \\
I & 3 & 3 & 12.4 & 21.868 \\
\hline
\end{tabular}

The ANOVA results for bonding strength are shown in Table 5. The $p$ value and individual parameter contribution percentage indicate that dipping time has a greater influence on the coating process compared to shellac concentration.

Table 5. ANOVA.

\begin{tabular}{ccccccc}
\hline Parameters & DF & SS & MS & F-Value & $p$-Value & \% Contribution \\
\hline Dipping time & 2 & 38.78 & 19.39 & 26.62 & 0.005 & 77.41 \\
Shellac concentration\% $w / w$ & 2 & 8.47 & 4.203 & 5.77 & 0.066 & 16.91 \\
Error & 4 & 2.93 & 0.7283 & & & \\
Total & 8 & 50.1 & & & & \\
\hline
\end{tabular}

A linear mathematical model was developed to study the effect of parameters on bonding strength using regression analysis and is expressed in Equation (1). The significance of the mathematical model is interpreted using the R-sq value. Usually, this value varies from zero to one and if the value obtained is nearing one, it indicates a good fit and can be used for predicting the bonding strength values. In the present study models developed for bonding strength have an R-sq value of $70.56 \%$.

$$
\text { Bonding strength }=-27.02+0.25 \mathrm{w}_{1}+2.367 \mathrm{w}_{2}
$$

Figure 7 shows the residual plots for bonding strength. The straight-line residual plot indicates that the residual errors are following a normal distribution and the coefficients in the model are significant.

To validate the developed mathematical model random values, parameters well within the range were selected and substituted. Experimental and predicted results showed slight deviations. Confirmation tests for a random experiment combination with $19 \mathrm{~s}$ and $13.2 \%$ of dipping time and shellac concentration respectively were conducted and the results are tabulated in Table 6.

Table 6. Confirmation test.

\begin{tabular}{ccc}
\hline \multicolumn{2}{c}{ Bonding Strength } \\
\hline Experimental result & Predicted results \\
\hline 9.231 & 8.974 \\
\hline
\end{tabular}




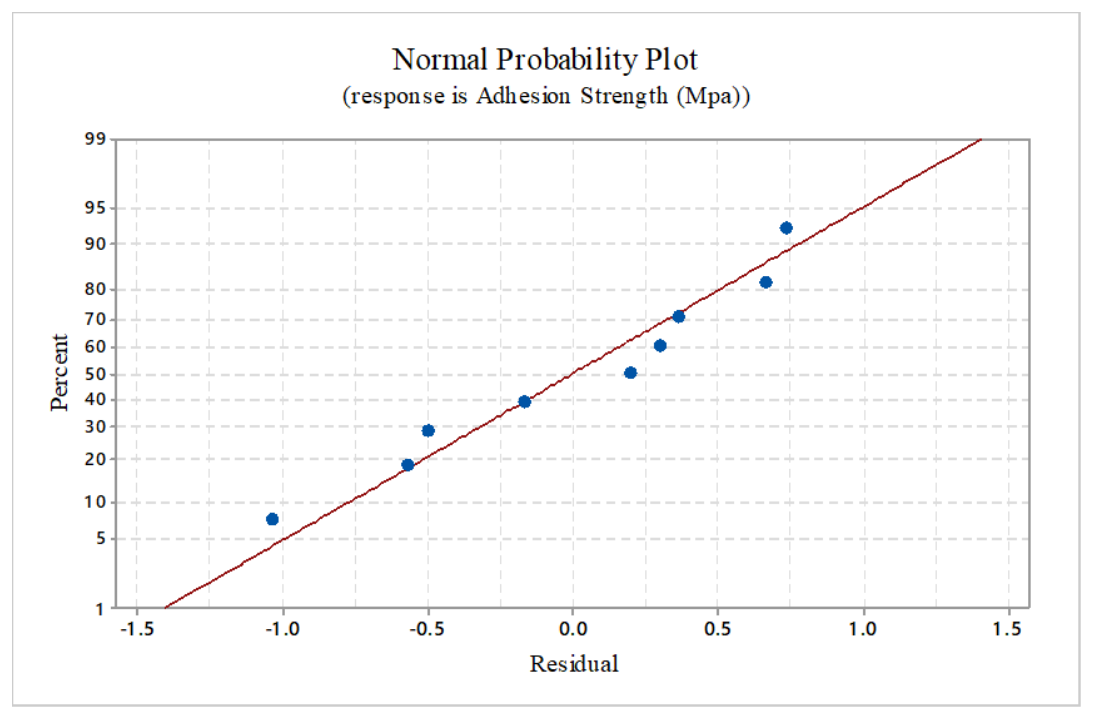

Figure 7. Normal probability plot.

\subsection{Dissolution and Cell Viability}

The dissolution behavior of the coating developed is evaluated by immersing it in the prepared SBF. The results are shown in Figure 8. It can be seen that the dissolution of Ca and $\mathrm{P}$ ions are almost constant indicating their stability in the body fluid environment. The dissolution rate of $\mathrm{Mg}$ ions is seen to increase slightly after the second week and thereafter it shows a constant value. The intermediately applied shellac layer is seen to provide stability for the developed coating.

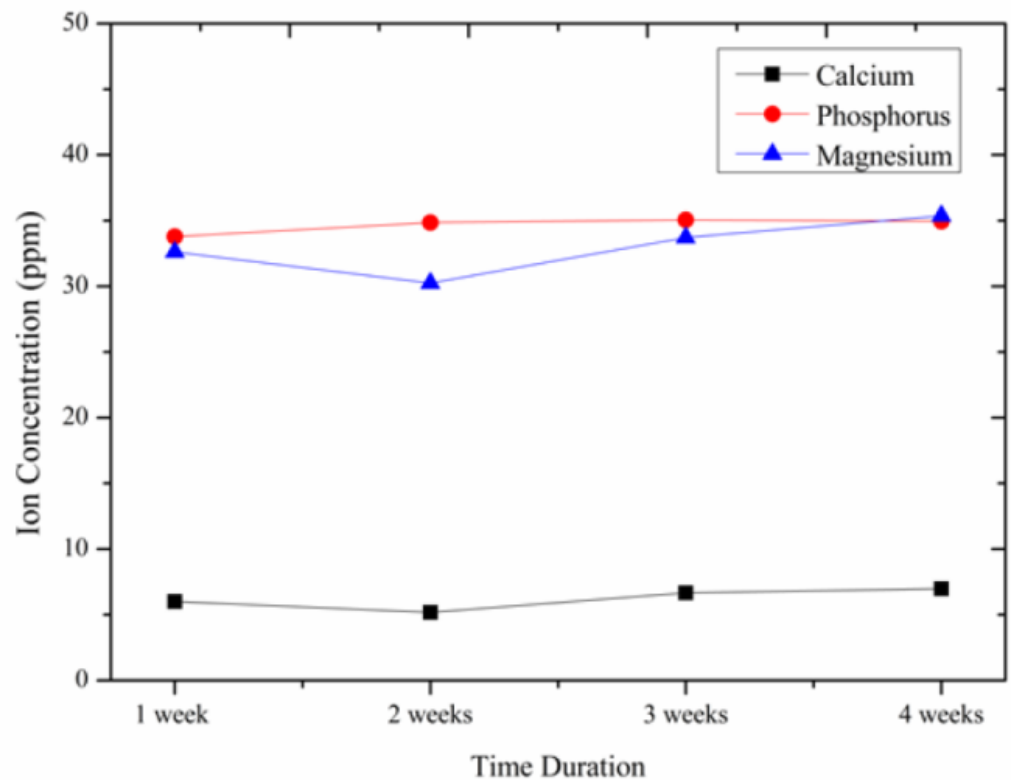

Figure 8. Change in ionic concentration.

The cell viability percentage of the Mg-HA coated substrate was calculated using the following Equation (2).

$$
\% \text { Cell Viability }=\frac{\mathrm{A}(\text { Substrate })-\mathrm{A}(\text { Blank })}{\mathrm{A}(\text { Control })-\mathrm{A}(\text { blank })}
$$

Here A (Substrate) is the absorbance value of the extract medium seeded with cells, A (Blank) is the absorbance value of CM, and A(control) is the CCM. The calculated value of 
cell viability percentage of control and Mg-HA coated substrates are illustrated in Figure 9. The extracted medium as mentioned was diluted to $50 \%$ (50\% extract medium $+50 \% \mathrm{CM}$ ), $25 \%(25 \%$ extract medium $+75 \% \mathrm{CM})$ and $12.5 \%(12.5 \%$ extract medium $+87.5 \% \mathrm{CM})$. The cell viability was computed for every single dilution percentage. With an increasing percentage of extract medium in the $\mathrm{CM}$, the cell viability was seen reducing. In every dilution proportion, $\mathrm{Mg}$-HA coated substrates are exhibiting better cell viability compared to the control. At $50 \%$ dilution percentage cell viability was approximately recorded to be $92 \%$ which is admissible as per ISO 10993-5 standards [41]. From the results obtained it is observed that the $\mathrm{Mg}$-HA coatings developed are non-toxic to the human body.

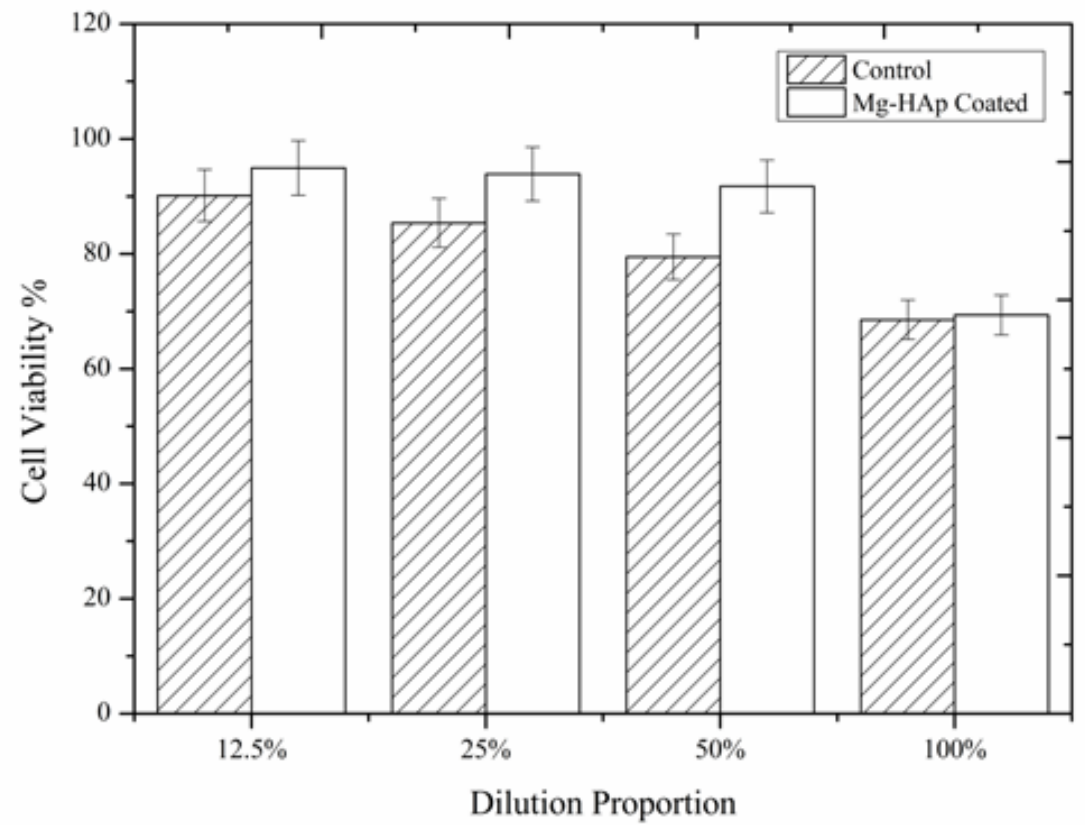

Figure 9. Cell viability at different dilution ratios.

The cell proliferation of MG-63 cells on extract medium was observed for 24, 48, and 72 hours. From Figure 10 it can be seen that the number of cells is proliferating in the extract medium at $12.5 \%$ and $25 \%$ dilution. At 72 hours duration for $50 \%$ dilution proportion, a decline in cell proliferation is noticed. More importantly, at 100\% dilution proportion, a significant increase in cell deaths is seen. The reduction in cell viability percentage at $100 \%$ dilution proportion can be justified by this cell death process. One probable reason for the cell death may be because the lack of space for the cells to grow. After a thrust point, the cells need more surface area for further multiplication. In this study, the surface area is constrained and it leads to overcrowding which results in cell death. 


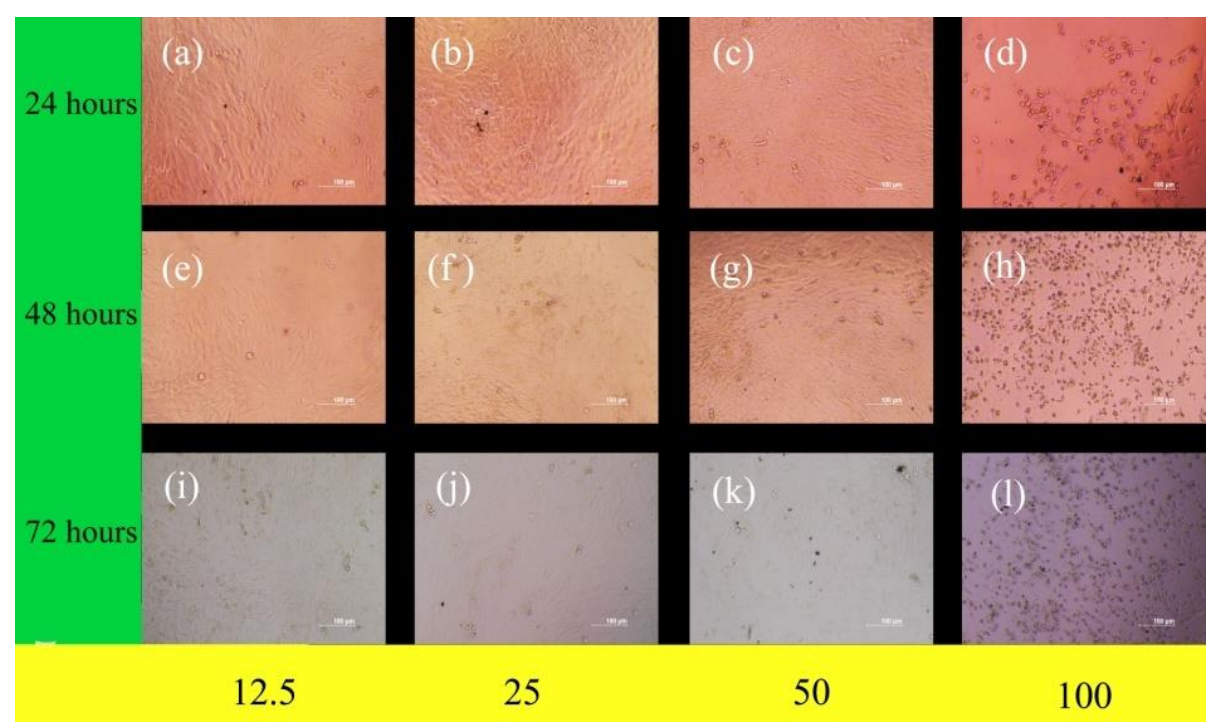

Figure 10. Microscopic images of MG-63 human cells seeded to different proportions of extract medium.

\subsection{Corrosion Studies}

The corrosion behavior of the coated substrates is confirmed by electrochemical studies in a simulated body fluid environment. The potentiodynamic polarization curves of the uncoated and Mg-HA coated substrates are plotted and shown in Figure 11. The $\mathrm{I}_{\text {corr }}$ value of uncoated and coated substrates was measured as $1.10 \times 10^{-6} \mathrm{~A}$ and $2.93 \times 10^{-8} \mathrm{~A}$ respectively. Corrosion resistance is proportional to the value of $\mathrm{I}_{\text {corr }}$. Here the coated substrate has a lower $\mathrm{I}_{\text {corr }}$ Value and so it exhibits better corrosion resistance. The corrosion resistance of the coated substrate improves because the thin film coating acts as a barrier to the substrate. If the thin film obtained on the substrate is non-uniform and porous, the substrate is exposed to the SBF environment. A further ionic release takes place and pitting corrosion starts to appear. Even a small amount of released debris may cause local inflammation, irritation, and tissue damage [42,43]. The thickness of the coating also plays an important part in corrosion studies. Thicker coatings tend to develop cracks at a rapid rate and therefore thin coating is suitable as a surface modification technique for metal implants [44].

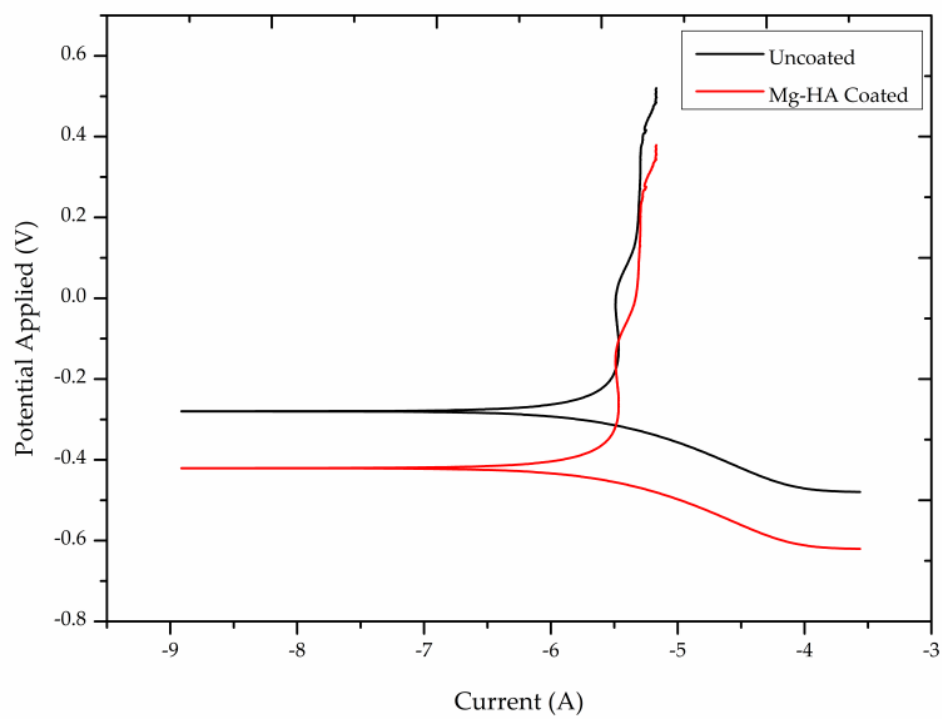

Figure 11. Potentiodynamic polarization curve of uncoated and Mg-HA coated substrates. 


\title{
4. Conclusion
}

The Mg-HA powder used for coating purposes was synthesized using a wet chemical method and was characterized using SEM, HR-TEM, EDS, and XRD analysis. The surface morphology of the powder using SEM analysis showed spherical-shaped particles. Similarly, nano-scale crystalline morphology of the prepared powders was observed using HR-TEM and it was noticed that the nano size of the powders enabled the preparation of a uniformly suspended colloidal solution. EDS analysis confirmed the incorporation of $\mathrm{Mg}$ in the HA lattice structure. A dip coating technique was used for coating the substrates. A thin film of Mg-HA was developed on Ti6Al4V substrate. The shellac layer applied in between the Mg-HA coating and the substrate improved the bonding strength and provided stability for the developed coating. The coating parameter values of the dip coating process were optimized using the Taguchi optimization technique. Regression models were developed to predict the bonding strength value.

Dissolution studies conducted for 4 weeks in SBF showed that the release of Ca, $\mathrm{P}$, and $\mathrm{Mg}$ ions into the body fluid was not that significant and it further indicated the adhesiveness of the developed coating onto the metal substrate. The cell viability studies performed using MG-63 osteosarcoma cell lines confirmed the non-toxic behavior of the developed coating and make it suitable for application in orthopedic and dental implants. Corrosion studies showed that $\mathrm{Mg}$-HA coated substrate has better corrosion resistance properties than the uncoated substrate.

These results suggest the use of Mg-HA coatings developed on Ti6Al4V for biocompatible applications. A specific application such as the combination of bone marrow mesenchymal stem cells with substituted HA [45,46] for promoting the osseointegration process and for reducing the bone healing period can be studied further. Initial studies reported that using $\mathrm{Mg}$-HA combined with stem cells yields good results [47]. Such composite coatings can also be applied to abutments and double conical connections, but further investigations on the effect of mechanical loading and torque required to loosen the screws must be carried out in a detailed manner. Implant stability also must be studied using some non-invasive techniques such as periotest, resonance frequency analysis, and implant insertion torque measurement [48] before suggesting it for clinical applications.

Author Contributions: R.A. has contributed to the experimental and analytical work of the research, K.K.S. has involved himself in the validation and evaluation of the findings reported in the paper, and R.A.R. contributed towards the optimization technique. All authors have read and agreed to the published version of the manuscript.

Funding: We did not receive any specific grant from funding agencies in the public, commercial, or not-for-profit sectors.

Institutional Review Board Statement: Not applicable.

Informed Consent Statement: Not applicable.

Data Availability Statement: The authors declare that data supporting the findings of this study are available within the article.

Acknowledgments: We would like to thank DST-SAIF, Cochin for providing all necessary support towards this research work.

Conflicts of Interest: The authors declare that they have no competing interests.

\author{
Abbreviations \\ Mg-HA Magnesium substituted Hydroxyapatite \\ XRD X-ray powder diffraction method \\ SEM Scanning Electron Microscopy \\ SBF Simulated body fluid
}




$\begin{array}{ll}\text { ICP-MS } & \text { Inductively Coupled Plasma-Mass Spectrometry } \\ \text { CM } & \text { complete medium } \\ \text { ETO } & \text { Ethylene oxide } \\ \text { MEM } & \text { Minimum essential medium } \\ \text { FBS } & \text { Fetal bovine solution } \\ \text { CCM } & \text { Cell culture medium } \\ \text { SCE } & \text { Saturated calomel electrode } \\ \text { DF } & \text { Degrees of freedom } \\ \text { SS } & \text { Sum of squares } \\ \text { MS } & \text { Mean square }\end{array}$

\section{References}

1. Fielding, G.A.; Roy, M.; Bandyopadhyay, A.; Bose, S. Antibacterial and biological characteristics of silver containing and strontium doped plasma sprayed hydroxyapatite coatings. Acta Biomater. 2012, 8, 3144-3152. [CrossRef] [PubMed]

2. Thian, E.S.; Huang, J.; Best, S.M.; Barber, Z.H.; Bonfield, W. Magnetron co-sputtered silicon-containing hydroxyapatite thin films-an in vitro study. Biomaterials 2005, 26, 2947-2956. [CrossRef] [PubMed]

3. Tite, T.; Popa, A.-C.; Balescu, L.; Bogdan, I.; Pasuk, I.; Ferreira, J.; Stan, G. Cationic substitutions in hydroxyapatite: Current status of the derived biofunctional effects and their in vitro interrogation methods. Materials 2018, 11, 2081. [CrossRef] [PubMed]

4. Šupová, M. Substituted hydroxyapatites for biomedical applications: A review. Ceram. Int. 2015, 41, 9203-9231. [CrossRef]

5. Boyd, A.R.; Rutledge, L.; Randolph, L.D.; Meenan, B.J. Strontium-substituted hydroxyapatite coatings deposited via a codeposition sputter technique. Mater. Sci. Eng. C 2015, 46, 290-300. [CrossRef] [PubMed]

6. Saini, M. Implant biomaterials: A comprehensive review. World J. Clin. Cases 2015, 3, 52-57. [CrossRef]

7. Tang, Y.; CHApell, H.F.; Dove, M.T.; Reeder, R.J.; Lee, Y.J. Zinc incorporation into hydroxylapatite. Biomaterials 2009, 30, $2864-2872$. [CrossRef] [PubMed]

8. Ren, F.; Xin, R.; Ge, X.; Leng, Y. Characterization and structural analysis of zinc-substituted hydroxyapatites. Acta Biomater. 2009, 5, 3141-3149. [CrossRef]

9. Chen, W.; Liu, Y.; Courtney, H.; Bettenga, M.; Agrawal, C.M.; Bumgardner, J.D.; Ong, J.L. In vitro anti-bacterial and biological properties of magnetron co-sputtered silver-containing hydroxyapatite coating. Biomaterials 2006, 27, 5512-5517. [CrossRef]

10. Mo, A.; Liao, J.; Xu, W.; Xian, S.; Li, Y.; Bai, S. Preparation and antibacterial effect of silver-hydroxyapatite/titania nanocomposite thin film on titanium. Appl. Surf. Sci. 2008, 255, 435-438. [CrossRef]

11. Viala, S.; Freche, M.; Lacout, J. Preparation of a new organic-mineral composite: Chitosan-hydroxyapatite. Ann. Chim. Sci. Des. Mater. 1998, 23, 69-72. [CrossRef]

12. Li, H.; Zhou, C.R.; Zhu, M.Y.; Tian, J.H.; Rong, J.H. Preparation and characterization of homogeneous hydroxyapatite/chitosan composite scaffolds via in-situ hydration. J. Biomater. Nanobiotechnol. 2010, 1, 42-49. [CrossRef]

13. Kong, L.; Gao, Y.; Cao, W.; Gong, Y.; Zhao, N.; Zhang, X. Preparation and characterization of nano-hydroxyapatite/chitosan composite scaffolds. J. Biomed. Mater. Res. Part A 2005, 75A, 275-282. [CrossRef]

14. Pang, X.; Zhitomirsky, I. Electrodeposition of composite hydroxyapatite-chitosan films. Mater. Chem.Phys. 2005, 94, $245-251$. [CrossRef]

15. Grandfield, K.; Zhitomirsky, I. Electrophoretic deposition of composite hydroxyapatite-silica-chitosan coatings. Mater.Charact. 2008, 59, 61-67. [CrossRef]

16. Shainberg, A.P.M.; Valério, P.; Zonari, A.; Oktar, F.N.; Ozyegin, L.S.; Graça, M.P.F.; Leite, M.F.; Goes, A.M. Attachment and proliferation of osteoblasts on lithium-hydroxyapatite composites. Adv. Mater. Sci. Eng. 2012, 2012, 1-10. [CrossRef]

17. Gibson, I.R.; Bonfield, W. Novel synthesis and characterization of an AB-type carbonate-substituted hydroxyapatite. J. Biomed. Mater. Res. 2001, 59, 697-708. [CrossRef]

18. Farzadi, A.; Bakhshi, F.; Solati-Hashjin, M.; Asadi-Eydivand, M.; abu Osman, N.A. Magnesium incorporated hydroxyapatite: Synthesis and structural properties characterization. Ceram. Int. 2014, 40, 6021-6029. [CrossRef]

19. Gayathri, B.; Muthukumarasamy, N.; VelautHAillai, D.; Santhosh, S.B.; asokan, V. Magnesium incorporated hydroxyapatite nanoparticles: Preparation, characterization, antibacterial and larvicidal activity. Arab. J. Chem. 2018, 11, 645-654. [CrossRef]

20. Mishra, V.K.; Bhattacharjee, B.N.; Parkash, O.; Kumar, D.; Rai, S.B. Mg-doped hydroxyapatite nanoplates for biomedical applications: A surfactant assisted microwave synthesis and spectroscopic investigations. J. Alloys Compd. 2014, 614, 283-288. [CrossRef]

21. Santos, G.G.; Nunes, V.L.C.; Marinho, S.M.O.C.; Santos, S.R.A.; Rossi, A.M.; Miguel, F.B. Biological behavior of magnesiumsubstituted hydroxyapatite during bone repair. Braz. J. Biol. 2021, 81, 53-61. [CrossRef]

22. Crespi, R.; Capparè, P.; Gherlone, E. Osteotome sinus floor elevation and simultaneous implant placement in grafted biomaterial sockets: 3 years of follow-up. J. Periodontol. 2010, 81, 344-349. [CrossRef] [PubMed]

23. Batchelar, D.L.; Davidson, M.T.M.; Dabrowski, W.; Cunningham, I.A. Bone-composition imaging using coherent-scatter computed tomography: Assessing bone health beyond bone mineral density. Med. Phys. 2006, 33, 904-915. [CrossRef] 
24. Pauwels, R.; Jacobs, R.; Singer, S.R.; Mupparapu, M. CBCT-based bone quality assessment: Are Hounsfield units applicable? Dentomaxillofacial Radiol. 2015, 44, 20140238. [CrossRef] [PubMed]

25. Han, Y.; Wei, Q.; Chang, P.; Hu, K.; Okoro, O.V.; Shavandi, A.; Nie, L. Three-dimensional printing of hydroxyapatite composites for biomedical application. Crystals 2021, 11, 353. [CrossRef]

26. Luo, Y.; Chen, S.; Shi, Y.; Ma, J. 3D printing of strontium-doped hydroxyapatite based composite scaffolds for repairing critical-sized rabbit calvarial defects. Biomed. Mater. 2018, 13, 065004. [CrossRef]

27. Golafshan, N.; Vorndran, E.; Zaharievski, S.; Brommer, H.; Kadumudi, F.B.; Dolatshahi-Pirouz, A.; Malda, J. Tough magnesium phosphate-based 3D-printed implants induce bone regeneration in an equine defect model. Biomaterials 2020, $261,120302$. [CrossRef]

28. Jemat, A.; Ghazali, M.J.; Razali, M.; Otsuka, Y. Surface Modifications and Their Effects on Titanium Dental Implants. BioMed Res. Int. 2015, 2015, 1-11. [CrossRef]

29. Farag, Y. Characterization of Different Shellac Types and Development of Shellac-Coated Dosage Forms. Ph.D. Thesis, The Faculty of Mathematics, Computer Science Andnatural Sciences, University of Hamburg, Hamburg, Germany, 2010.

30. Mavis, B.; Tas, A. Dip coating of calcium hydroxyapatite on Ti-6Al-4V substrates. J. Am. Ceram. Soc. 2004, 83, 989-991. [CrossRef]

31. ASTM D7234-19 Standard Test Method for Pull-Off Adhesion Strength of Coatings on Concrete Using Portable Pull-off Adhesion Testers; ASTM International: West Conshohocken, PA, USA, 2019.

32. IS 3203: 1982 Methods of Testing Local Thickness of Electroplated Coatings; Bureau of Indian Standards: Old Delhi, India, 2016.

33. Kokubo, T.; Takadama, H. How useful is SBF in predicting in vivo bone bioactivity? Biomaterials 2006, 27, 2907-2915. [CrossRef] [PubMed]

34. ISO 10993-14 Biological Evaluation of Medical Devices-Part 14: Identification and Quantification of Degradation Products from Ceramics; International Organization for standardization: Geneva, Switzerland, 2019.

35. ISO 10993-12 Biological Evaluation of Medical Devices_Part 12: Sample preparation and Reference Materials; International Organization for standardization: Geneva, Switzerland, 2021.

36. Kamachimudali, U.; Sridhar, T.M.; Raj, B. Corrosion of bio implants. Sadhana 2003, 28, 601-637. [CrossRef]

37. ASTM G5-94(2011)e1 Standard Reference Test Method for Making Potentiostatic and Potentiodynamic Anodic Polarization Measurements; ASTM International: West Conshohocken, PA, USA, 2011.

38. Lotsari, A.; Rajasekharan, A.K.; Halvarsson, M.; Andersson, M. Transformation of amorphous calcium phosphate to bone-like apatite. Nat.Commun. 2018, 9, 4170. [CrossRef]

39. Mo, N.; Zhu, Z.; Zhu, Y.; Liu, Y.; Wang, X.; Yang, H.; Zhao, N. Purification behavior of Zn(II) in water by magnesium hydroxyapatite: Surface complexation, and dissolution-precipitation. Int. J. Environ. Res. Public Health 2020, 17, 3804. [CrossRef]

40. Suchanek, W.L.; Byrappa, K.; Shuk, P.; Riman, R.E.; Janas, V.F.; TenHuisen, K.S. Preparation of magnesium-substituted hydroxyapatite powders by the mechanochemical-hydrothermal method. Biomaterials 2004, 25, 4647-4657. [CrossRef]

41. ISO 10993-5 Biological Evaluation of Medical Devices_Part 5: Tests for in Vitro Cytotoxicity; International Organization for standardization: Geneva, Switzerland, 2017.

42. Eliaz, N. Corrosion of metallic biomaterials: A review. Materials 2019, 12, 407. [CrossRef]

43. Munir, S.; Oliver, R.A.; Zicat, B.; Walter, W.L.; Walter, W.K.; Walsh, W.R. The histological and elemental characterisation of corrosion particles from taper junctions. Bone Jt. Res. 2016, 5, 370-378. [CrossRef] [PubMed]

44. Li, M.; Jin, Z.-X.; Zhang, W.; Bai, Y.-H.; Cao, Y.-Q.; Li, W.-M.; Li, A.-D. Comparison of chemical stability and corrosion resistance of group IV metal oxide films formed by thermal and plasma-enhanced atomic layer deposition. Sci. Rep. 2019, 9, 10438. [CrossRef] [PubMed]

45. Yang, H.W.; Lin, M.H.; Xu, Y.Z.; Shang, G.W.; Wang, R.R.; Chen, K. Osteogenesis of bone marrow mesenchymal stem cells on strontium-substituted nano-hydroxyapatite coated roughened titanium surfaces. Int. J. Clin. Exp. Med. 2015, 8, 257-264. [PubMed]

46. Michel, J.; Penna, M.; Kochen, J.; Cheung, H. Recent advances in hydroxyapatite scaffolds containing mesenchymal stem cells. Stem Cells Int. 2015, 2015, 1-13. [CrossRef] [PubMed]

47. Kim, D.-H.; Shin, K.-K.; Jung, J.S.; Chun, H.H.; Park, S.S.; Lee, J.K.; Yoon, S.-Y. The role of magnesium ion substituted biphasic calcium phosphate spherical micro-scaffolds in osteogenic differentiation of human adipose tissue-derived mesenchymal stem cells. J. Nanosci. Nanotechnol. 2015, 15, 5520-5523. [CrossRef] [PubMed]

48. Baldi, D.; Lombardi, T.; Colombo, J.; Cervino, G.; Perinetti, G.; Di Lenarda, R.; Stacchi, C. Correlation between Insertion Torque and Implant Stability Quotient in Tapered Implants with Knife-Edge Thread Design. BioMed Res. Int. 2018, 2018, 7201093. [CrossRef] [PubMed] 